\title{
Financial Flexibility During the Pre- and Post-Global Financial Crisis Periods
}

\author{
Weihan Cui ${ }^{\mathrm{a}, 1}$ \\ ${ }^{a}$ Department of Economics, Nagoya University of Economics, Japan
}

\begin{abstract}
This paper investigates the determinants of financial flexibility of Japanese firms before and after the global financial crisis. In the pre-crisis period, growth opportunity has a positive effect on financial flexibility, but in the postcrisis period, this effect turns to negative and is especially strong for financially constrained firms. These results indicate that in normal time, the Japanese firms pursue financial flexibility for investment demand as argued in previous literature. During difficult time, investment environment deteriorates and investment declines, therefore the firms with less growth opportunity accelerate to accumulate financial flexibility, especially for financially constrained firms as they suffer more than others in such a period. Enhancing the investment environment can improve the efficiency of corporate capital and financial support from banking system may ease the stress of financially constrained firms in post-crisis period.
\end{abstract}

Keywords. Financial flexibility; Debt conservatism; Global financial crisis

\section{Introduction}

Financial flexibility refers to a certain ability of a firm, which enables it reacts to investment demand or crisis in a timely and necessarily way. After the 2008 Global Financial Crisis, acquiring and maintaining financial flexibility have become increasingly important for firms. Firms pursue financial flexibility by holding enormous cash holdings or debt capacity, which means accumulating cash or decreasing leverage. A substantial number of firms choose to hold low or even zeroleverage [1] [2], which also known as conservative debt policy [3]. These conservative debt policies can provide firms with the capability of issuing debt when the necessity arises, and therefore provide financial flexibility.

Due to the strong bank-firm relationship, though [4] argue that zero-leverage is an international phenomenon, Japan has extremely low zero-leverage firm ratio. [5] analyzes Japanese zero-leverage firms and concludes that Japanese firms are kept away from zero-leverage by enormous bank power. Having positive gross leverage does not mean that Japanese firms are not conservative, in fact, Japanese firms choose to simultaneously have positive gross debt and sufficient cash holdings which is enough to repay all the debt. This behavior results in a positive gross debt ratio and a negative net debt ratio, and this so-called "non-positive debt policy" becomes the conservative

\footnotetext{
${ }^{1}$ Corresponding Author, Weihan Cui, Department of Economics, Nagoya University of Economics, 61-1 Uchikubo, Inuyama City, Aichi Prefecture 484-8504, Japan; Email address: cui-w@nagoya-ku.ac.jp. This research is funded by Yamada Memorial Trust Fund for Promotion of Scholarly Research.
} 
debt policy of Japanese firms. By the end of 2017, 59\% of Japanese firms are nonpositive net debt firms (the data comes from Nikkei), the non-positive debt policy is truly the main stream in Japan.

Though the determinants of conservative debt policy are still unclear, the previous literature does have one consensus: the firms with more growth opportunity are more likely to adopt conservative debt policy [1] [4] [6] [7] [8] [9] [10]. The empirical results show that firms with higher market-to-book ratio (which is the proxy of growth opportunity) are more likely to adopt conservative debt policy, which implies that firms save debt capacity and accumulate financial flexibility for valuable investment opportunity in the future.

Because conservative debt policies provide financial flexibility, the Japanese firms with non-positive net debt can also be regarded as firms with considerable financial flexibility. If Japanese firms accumulate financial flexibility for future investment opportunity as previous literature argued, a positive effect of growth opportunity on the possibility of non-positive net debt is expected. However, this effect is negative for Japanese firms [11]. This evidence indicates that the lack of valuable investment opportunity limits the use of funds, meanwhile, Japanese firms resume to accumulate cash holdings in recent years, which together results in an increase of non-positive net debt firms.

During and after the global financial crisis in 2008, external credit supply becomes constrained and financial flexibility becomes more valuable than normal times. Since the number of Japanese non-positive net debt firms dramatically increased right after the global financial crisis, it is natural to consider that the financial crisis is one of the determinants of financial flexibility. This paper analyzes the determinants of financial flexibility of Japanese firms before and after the global financial crisis. The results suggest that, in pre-crisis period, there exists a positive effect of growth opportunity on the financial flexibility, which is in line with the most previous literature. However, this positive effect turns to negative in the post-crisis period and gradually weakened as time goes by. Furthermore, the negative effect of growth opportunity is extremely strong for financially constrained firms before the crisis and gradually weakened afterward. These results indicate that there are different motivations for accumulating financial flexibility based on the macro environment. In normal time, firms accumulate cash holdings to prepare for the future investment opportunity; in difficult time, investment environment deteriorates and firms with less growth opportunity accumulate financial flexibility naturally due to decreased investment. Meanwhile, financially constrained firms suffer more than others and are more urgent to save financial flexibility in the post-crisis period.

This paper present empirical evidence which contributes to the understanding of determinants of financial flexibility, while previous literature focus on the positive relation between growth opportunity and financial flexibility, this paper provides results which show that there exits different growth opportunity-financial flexibility relation under different macro environment. This paper also contributes to the understanding of Japanese conservative debt policy, especially the determinants of nonpositive net debt of Japanese firms around the global financial crisis, providing possible explanation for the existing empirical results of Japanese conservative debt policy that differ from the other countries.

The remainder of this paper is organized as follows. Section 2 explains the main hypothesis and econometric methodology. Section 3 presents the main results, and Section 4 concludes the paper. 


\section{Hypotheses and Methodology}

With market friction's existence, firms eschew debt to mitigate investment distortions and prepare for valuable future investments or unexpected cash shortfalls [12]. [8] study the firms that persistently maintain low leverages and find that such firms are highly profitable, generate sufficient cash flows, have higher growth opportunity, and are less likely to be financially constrained. As substantial previous literature agree that firms with more growth opportunity are more likely to have lower leverage, in other words, more debt capacity or financial flexibility.

While U.S firms take the equity market as their prior capital resource, Japanese firms mainly rely on banks for borrowing [13]. The relationship with their "main bank" is important, because this bank relationship is not only regarded as access to external funds, but also (to some extent) plays a role as a guarantee of a firm's performance; those firms which do not have a main bank may be considered as not bankrelationship-worthy. Furthermore, the bank-firm relationship is expensive to recover if terminated [5], so the Japanese firms are reluctant to repay all the debt. Therefore, holding more cash than debt becomes the conservative debt policy in Japan. As Figure 1 shows, the number of Non-positive net debt (NPND) firms has been generally increased in recent years.

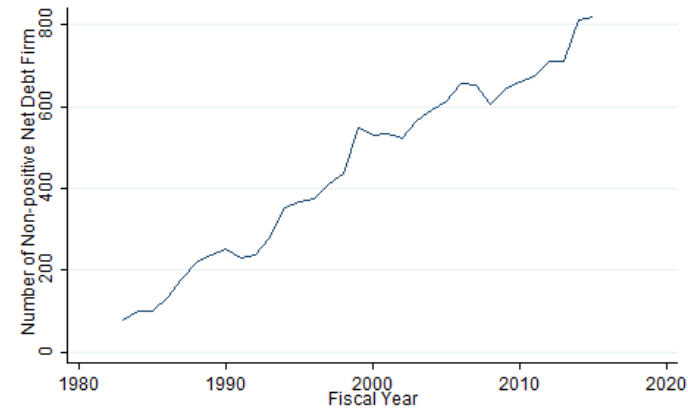

Figure 1. Trend of Non-positive Net Debt Firms in Japan.

The previous literature adopts various proxies of financial flexibility, such as the market value of the real estate, short-term debt, cash holdings, and excess cash. Given the prevalence of NPND firms in Japan, this paper adopts two proxies of financial flexibility. One proxy is a dummy variable of NPND, which takes the value of one if a firm has non-positive net debt and zero otherwise; the other proxy is excess cash holdings, defined as the cash holding minus the debt.

A positive shock to firms' financial flexibility will decrease the value of cash and therefore the amount of cash holdings, especially for financially constrained firms. The global financial crisis is associated with a negative demand shock [14] and caused a decline in growth opportunity [15]. Therefore, the value of cash and the amount of cash holdings are supposed to increase after the crisis. Meanwhile, Japan is known for low level of growth opportunity, lack of growth opportunity encourages the stockpiling of cash holding. Since that exists a positive relationship between growth opportunity and leverage for low growth firms [16], with other things being equal, a lower leverage means a higher possibility of having NPND. Since the previous literature suggests that the effect of growth opportunity on NPND is negative [11], it is possible that this relationship is stronger in post-crisis period than pre-crisis period. 
Hypothesis 1: There exists a negative relationship between growth opportunity and the possibility of accumulating financial flexibility, is stronger in post-crisis period than pre-crisis period.

Furthermore, financially constrained firms value cash more than others [17] [18]. Firms with poor cash holdings before the crisis are likely to experience more severe investment decline [19], and financially constrained firms are also more likely to have payout reduction in the post-crisis period [15]. During the financial crisis, financially constrained firms are more sensitive to the deteriorated environment and are more urgent to accumulate cash holdings. Therefore, the negative relationship between growth opportunity and NPND could be stronger for financially constrained firms.

Hypothesis 2: The negative relation between growth opportunity and the possibility of accumulating financial flexibility is especially strong for financially constrained firms.

The original data consist of the firms which are contained in Nikkei NEEDSFinancial QUEST data set during the period from 1983 to 2015. The global financial crisis period is set from 2005 to 2012 . The pre-crisis period is defined as from 2005 to 2007; the post-crisis period is defined as from 2008 to 2010 and extended into 2008 to 2012 in the additional specifications.

Table 1. Statistic Summary

\begin{tabular}{ccccccc}
\hline & \multicolumn{3}{c}{$\mathbf{2 0 0 5} \mathbf{2 0 1 0}$} & & $\mathbf{2 0 0 5} \mathbf{2 0 1 2}$ & Std. Dev. \\
\hline & Obs & Mean & Std. Dev. & Obs & Mean & 0.24 \\
Excess Cash & 6085 & -0.06 & 0.23 & 5730 & -0.05 & 0.47 \\
NPND & 6085 & 0.32 & 0.46 & 5730 & 0.33 & 0.36 \\
[M/B] & 5884 & 1.23 & 0.70 & 5632 & 0.93 & 1.49 \\
Size & 5884 & 10.87 & 1.43 & 5632 & 10.87 & 0.18 \\
Tangibility & 5884 & 0.30 & 0.17 & 5632 & 0.31 & 0.00 \\
Profitability & 3261 & 0.00 & 0.00 & 2820 & 0.00 & 0.02 \\
Dividend & 5275 & 0.01 & 0.01 & 5444 & 0.01 & 0.13 \\
[R\&D] & 4221 & 0.03 & 0.15 & 4081 & 0.03 & 0.67 \\
Age & 5884 & 2.31 & 0.74 & 5632 & 2.53 & 0.14 \\
CAPEX & 5884 & 0.01 & 0.08 & 5632 & -0.02 & \\
\hline
\end{tabular}

Excess cash is defined as cash holding + securities in liquid asset - short-term debt - long-term debt - bond, scaled by total asset. NPND is a dummy variable that represents the non-positive net debt position, which equals one if a firm has nonpositive net debt and zero otherwise. $[\mathrm{M} / \mathrm{B}]$ is the ratio of the market asset to the book asset. Size is the natural $\log$ of the total asset. Tangibility is defined as the tangible asset divided by the total asset. Profitability is defined as the sum of income and depreciation, divided by the total asset. Dividend is the ratio of dividend to the total asset. $[R \& D]$ is defined as the ratio of $[R \& D]$ to sales. Age is the natural log of the number of years that a firm appears in the sample period. CAPEX represents the capital expenditure, defined as the difference of fixed asset divided by the total asset. The summary statistics are shown in Table 1.

\section{Main Results}

The analysis is conducted in two steps. First, following [20], the dependent variable NPND dummy which represents both conservative debt position and sufficient financial flexibility, is regressed on the main variables ([M/B], Size, Tangibility, 
Profitability, Dividend) and control variables ([R\&D], Age, CAPEX). Then, the dependent variable will be replaced by excess cash. The regressions are applied to fixed effect to control for the time-invariant variables. All independent variables are taken one lag to control the endogeneity issue.

Table 2 shows the main results of logistic regression for all firms, the dependent variable is the dummy variable NPND. Though insignificantly, the $[\mathrm{M} / \mathrm{B}]$ is negative in 2005-2010, which is in the line with [11]. However, the sign of [M/B] is significantly positive in 2005-2007, which means that before the crisis, the firms with more growth opportunity are more likely to accumulate financial flexibility. This result is contrast to the [11], but consistent with the previous literature on low and zero-leverage.

Table 2. Panel analysis of NPND in Pre-and Post-financial crisis period

\begin{tabular}{ccccc}
\hline & $\mathbf{( 1 )}$ & $\mathbf{( 2 )}$ & $\mathbf{( 3 )}$ & $\mathbf{( 4 )}$ \\
\hline VARIABLES & $2005 \sim 2010$ & $2005 \sim 2007$ & $2008 \sim 2010$ & $2008 \sim 2012$ \\
{$[\mathrm{M} / \mathrm{B}]$} & -0.250 & $1.827^{*}$ & $-4.492^{* *}$ & $-1.571^{*}$ \\
& $(0.366)$ & $(1.044)$ & $(1.906)$ & $(0.862)$ \\
Size & $-3.558^{* * *}$ & -3.182 & $-13.495^{* * *}$ & $-7.474 * * *$ \\
& $(1.016)$ & $(2.716)$ & $(3.945)$ & $(1.590)$ \\
Tangibility & $-8.545^{* *}$ & -1.496 & $-40.800^{* * *}$ & $-24.749 * * *$ \\
& $(3.744)$ & $(8.607)$ & $(13.128)$ & $(5.300)$ \\
Profitability & $750.096^{*}$ & 673.909 & $3,460.176$ & $1,187.199$ \\
& $(428.166)$ & $(915.963)$ & $(2,296.441)$ & $(826.360)$ \\
Dividend & $86.451^{* *}$ & 147.449 & -32.344 & 28.061 \\
& $(36.475)$ & $(130.032)$ & $(61.047)$ & $(35.426)$ \\
[R\&D] & $-38.069^{* *}$ & -58.640 & -43.228 & -12.994 \\
& $(17.643)$ & $(53.733)$ & $(38.029)$ & $(19.143)$ \\
Age & $2.182^{* * *}$ & 2.547 & 2.063 & $2.858^{* * *}$ \\
& $(0.583)$ & $(1.948)$ & $(1.841)$ & $(0.949)$ \\
CAPEX & 2.437 & 4.889 & 8.459 & 1.467 \\
& $(2.296)$ & $(5.174)$ & $(5.820)$ & $(2.145)$ \\
Observations & 560 & 156 & 174 & 509 \\
Number of firms & 125 & 56 & 64 & 125 \\
\hline
\end{tabular}

In 2008-2010 period, the signs of [M/B] becomes strongly significant and negative. As the post-crisis timespan extended to 2008-2012, the negative effect of [M/B] weakens and the significance compromises a little. The hypothesis H1 is supported.

These results imply that the 2008 global financial crisis triggered a fierce negative effect of growth opportunity on the financial flexibility, but this motivation dries out as the time goes by. Though previous literature of Japanese conservative debt policy argue that Japanese firms accumulate financial flexibility because they have nowhere to invest, but these results suggest that, in normal time, Japanese firms' behavior is not different from the other countries' firms. They pursue financial flexibility and prepare for future investment opportunity, which is also referred as "precautionary motivation". One possible explanation for the negative relation between growth opportunity and conservative debt policy in [11] is that, the negative relation appears in the post-crisis period is so strong that it biased the result for the whole sample period. As time goes by, the impact of global financial crisis fades away and the positive relation revives, therefore the negative relation weakens gradually.

Table 3. Panel analysis of NPND in Post-financial crisis period for firms that have not been NPND in 2005 2007 (Column 1 and 2) and firms that have never been NPND before 2008 (Column 3 and 4)

\begin{tabular}{ccccc}
\hline & $\mathbf{( 1 )}$ & $\mathbf{( 2 )}$ & $\mathbf{( 3 )}$ & $\mathbf{( 4 )}$ \\
\hline VARIABLES & $2008 \sim 2010$ & $2008 \sim 2012$ & $2008 \sim 2010$ & $2008 \sim 2012$ \\
{$[\mathrm{M} / \mathrm{B}]$} & $-0.722^{*}$ & 0.110 & $-4.025^{* *}$ & -0.412
\end{tabular}




$\begin{array}{ccccc} & (0.432) & (0.262) & (1.568) & (0.469) \\ \text { Size } & -3.552^{* * *} & -4.438^{* * *} & -4.459^{* * *} & -5.645 * * * \\ & (0.754) & (0.769) & (1.301) & (1.356) \\ \text { Tangibility } & -17.974 * * * & -16.811^{* * *} & -14.517 * * & -13.559^{* *} \\ & (4.044) & (3.266) & (6.916) & (5.269) \\ \text { Profitability } & 325.385 & -2.829 & 818.311 & -20.628 \\ & (668.098) & (124.541) & (922.226) & (147.417) \\ \text { Dividend } & 90.836 * * & 122.580^{* * *} & 170.403 * * & 159.448^{* * *} \\ & (41.399) & (37.766) & (66.333) & (57.548) \\ {[R \& D]} & -7.665 & -9.181 & -76.259 & -39.813 \\ & (23.384) & (14.471) & (51.499) & (41.430) \\ \text { Age } & 2.825 * * * & 3.848 * * * & 5.106 * * & 7.382 * * * \\ & (0.444) & (0.442) & (1.000) & (1.020) \\ \text { CAPEX } & -2.918 & -2.715 & -1.610 & -3.556 \\ & (2.344) & (2.119) & (4.582) & (3.654) \\ \text { Observations } & 546 & 877 & 332 & 547 \\ \text { Number of firms } & 57 & 90 & 35 & 57\end{array}$

To investigate the determinants of financial flexibility of firms with potential financial constraints, a specification of analysis that focuses on the newly-becoming NPND firms in the post-crisis period is conducted. The results are showed in Table 3. The same logistic regression in Table 2 is applied to the firms that (1) do not have NPND in the pre-crisis period i.e. 2005-2007 (Column 1 and 2), (2) do not have NPND in all years before the crisis i.e. before 2008 (Column 3 and 4). Again, there is a strong negative effect of $[\mathrm{M} / \mathrm{B}]$ on financial flexibility in the post-crisis period, and this negative effect weakens as the timespan expanded. Meanwhile, the negative effect is strongest for firms that have not been NPND firms before the financial crisis, the hypothesis $\mathrm{H} 2$ is supported by these results.

If we take the absent record of NPND before the financial crisis as the sign of being financially constrained, these results can also be comprehended as follows: in the post-crisis period, growth opportunity has the strongest negative effect on financial flexibility for the most financially constrained firms. Such financially constrained firms are likely to accumulate cash holdings to mitigate financial frictions and save more aggressively when the situation deteriorates [21]. However, the strong effect of [M/B] may also arise from the desire for the market reputation, as the least evaluated firms in the equity market suffer more than others, such financially constrained firms may have stronger motivation to pursue financial flexibility to acquire market reputation. Meanwhile, during the global financial crisis, some of the Japanese firms experienced severe capital shortage. As Japan is a bank-centered economy, cannot borrow from bank means that firms need to rely on cash holdings. This may be another reason for the acceleration of accumulating financial flexibility of financially constrained firms after the crisis.

Though NPND firms are considered as financially flexible, there may exist huge differences in the excess cash between each firm. To further investigate the relation between the thickness of financial flexibility and firms' growth opportunity, another specification using the amount of excess cash as the dependent variable is conducted. The results are displayed in Table 4. Column (1) and (2) show the results of the whole timespan from 2005 to 2010 , Column (3) and (4) show the pre-crisis period results (from 2005 to 2007), Column (5) and (6) show the results of the post-crisis period (from 2008 to 2010). For the timespan of 2005-2010, [M/B] ratio shows significantly positive signs, which implies a positive effect of growth opportunity on excess cash. This positive effect of growth opportunity on excess cash is stronger in the pre-crisis 
period than in the whole timespan and disappears in the post-crisis period. These results suggest that, in the pre-crisis period, firms with more growth opportunity are more likely to accumulate financial flexibility. Though this effect disappears in the post-crisis period 2008-2010, the results of timespan 2005-2010 is significantly positive, which indicates that the positive effect before the crisis is sufficiently strong. These results reinforce the integrity of the corresponding results in Table 2.

Table 4. Panel analysis of financial flexibility in Pre-and Post-financial crisis period of all firms with fixed effect

\begin{tabular}{|c|c|c|c|c|c|c|}
\hline & (1) & (2) & (3) & (4) & (5) & (6) \\
\hline \multicolumn{7}{|l|}{ VARIABLE } \\
\hline $\mathrm{S}$ & 2005 2010 & $2005 \sim 2010$ & $2005-2007$ & $2005-2007$ & $2008-2010$ & $2008-2010$ \\
\hline \multirow[t]{2}{*}{ [M/B] } & $0.011 * *$ & $0.017 * * *$ & $0.028 * * *$ & $0.027 * * *$ & 0.006 & 0.002 \\
\hline & $(0.005)$ & $(0.005)$ & $(0.006)$ & $(0.006)$ & $(0.013)$ & $(0.013)$ \\
\hline \multirow[t]{2}{*}{ Size } & $-0.089 * * *$ & $-0.097 * * *$ & $-0.070 * * *$ & $-0.081 * * *$ & $-0.154 * * *$ & $-0.128 * * *$ \\
\hline & $(0.009)$ & $(0.009)$ & $(0.014)$ & $(0.017)$ & $(0.017)$ & $(0.018)$ \\
\hline \multirow[t]{2}{*}{ Tangibility } & $-0.390 * * *$ & $-0.393 * * *$ & $-0.235 * * *$ & $-0.240 * * *$ & $-0.269 * * *$ & $-0.271 * * *$ \\
\hline & $(0.033)$ & $(0.033)$ & $(0.054)$ & $(0.055)$ & $(0.058)$ & $(0.057)$ \\
\hline \multirow[t]{2}{*}{ Profitability } & $2.339 * * *$ & $2.366 * * *$ & 1.378 & 1.329 & 1.077 & 0.961 \\
\hline & $(0.828)$ & $(0.824)$ & (1.001) & (1.001) & (1.687) & (1.631) \\
\hline \multirow[t]{2}{*}{ Dividend } & 0.175 & 0.120 & $2.672 * * *$ & $2.548 * * *$ & $-2.050 * * *$ & $-1.033 *$ \\
\hline & $(0.161)$ & $(0.161)$ & $(0.798)$ & $(0.806)$ & $(0.538)$ & $(0.544)$ \\
\hline \multirow[t]{2}{*}[\mathrm{R}\&\mathrm{D}]{} & & $-0.584 * * *$ & & $-0.667^{*}$ & & -0.241 \\
\hline & & $(0.197)$ & & $(0.391)$ & & $(0.288)$ \\
\hline \multirow[t]{2}{*}{ Age } & & $0.036 * * *$ & & 0.007 & & $0.136 * * *$ \\
\hline & & $(0.007)$ & & $(0.014)$ & & $(0.016)$ \\
\hline \multirow[t]{2}{*}{ CAPEX } & & $0.038^{*}$ & & 0.022 & & $0.072 * *$ \\
\hline & & $(0.020)$ & & $(0.031)$ & & $(0.028)$ \\
\hline \multirow[t]{2}{*}{ Constant } & $0.955 * * *$ & $0.954 * * *$ & $0.658 * * *$ & $0.781 * * *$ & $1.643 * * *$ & $0.998 * * *$ \\
\hline & $(0.102)$ & $(0.109)$ & $(0.160)$ & $(0.182)$ & $(0.194)$ & $(0.225)$ \\
\hline Observations & 3,716 & 3,716 & 1,845 & 1,845 & 1,871 & 1,871 \\
\hline & 0.081 & 0.093 & 0.079 & 0.082 & 0.096 & 0.161 \\
\hline \multicolumn{7}{|l|}{ Number of } \\
\hline firms & 967 & 967 & 806 & 806 & 765 & 765 \\
\hline
\end{tabular}

\section{Conclusion}

This paper investigates the financial flexibility preference of Japanese firms during the global financial crisis period. The main results are as follows: (1) in the pre-crisis period, firms with more growth opportunity accumulate financial flexibility, (2) in the post-crisis period, firm with less growth opportunity accumulate financial flexibility, (3) in the post-crisis period, financially constrained firms accumulate financial flexibility more aggressive than the others, (4) these results are robust for an alternative measure of financial flexibility as excess cash.

Japan is known for low growth opportunity, it is not surprising that firms accumulate cash holdings and decrease net leverage when they have few investments. Previous literature on Japanese conservative debt policy argue that this negative effect of growth opportunity on financial flexibility dominants Japanese firms' debt policy, however, this paper provides another explanation for this phenomenon. At least in normal time, Japanese firms pursue financial flexibility for investment opportunity as traditional financial flexibility theory argues. The uncommon negative effect only appears after the global financial crisis, the deteriorated investment environment 
triggers this negative effect of growth opportunity on financial flexibility and financial constraint deepens it.

For financially constrained firms, the experience of capital shortage during the financial crisis may force them to save aggressively in the post-crisis period, substantial financial support is expected to ease their difficulties. Furthermore, the switch of relation between growth opportunity and financial flexibility may also arise from the different financing cost that the firms faced and therefore different order between cash and debt in different periods [22], which should be further investigated.

\section{References}

[1] DeAngelo H, DeAngolo L. Capital Structure, Payout Policy, and Financial Flexibility. Marshall School of Business Working Paper 2007; No. FBE 02-06. Loss Angeles, CA: University of Southern California.

[2] Denis D J. Financial flexibility and corporate liquidity. Journal of Corporate Finance 2011; 17: 667-674.

[3] Graham J R. How big are the tax benefits of debt. Journal of Finance 2000; 55(5): 1901-1941.

[4] Bessler W, Drobetz W, Haller R, Meier I. International Zero-leverage Phenomenon. Journal of Corporate Finance 2013;23: 196-221.

[5] Takami Shigeo. Factors inhibiting Japanese firms from zero leverage: financial constraints and bank relationships. Asia-Pacific Journal of Accounting \& Economics 2016; 23(2): 161-176.

[6] Byoun S, Xu Z. Why Do Some Firms Go Debt-Free? Asia-Pacific Journal of Financial Studies 2013;42(1): 1-38.

[7] Dang V A. An Empirical Analysis of Zero-leverage Firms: Evidence from the UK. International Review of Financial Analysis 2013; 30: 189-202.

[8] Minton B A, Wruck K H. Financial Conservatism: Evidence on Capital Structure from Low Leverage Firms. Working Paper, 2001. Columbus, Ohio State University.

[9] Opler T, Pinkowitz L, Stulz R, Williamson R. The determinants and implications of corporate cash holdings. Journal of Financial Economics 1999; 52: 3-46.

[10] Strebulaev I A, Yang B. The Mystery of Zero-leverage Firms. Journal of Financial Economics 2013; 109(1): 1-23.

[11] Cui W. Is debt conservatism the solution to financial constraints? An empirical analysis of Japanese firms. Applied Economics 2020;52(23): 2526-2543.

[12] Gamba A, Triantis A J. The value of financial flexibility. Journal of Finance 2008; 63(5): 2263-2296.

[13] Gilbson M. Can bank health affect investment? Evidence from Japan. Journal of Business 1995; 68: 281-308.

[14] Mian A, Sufi A. The great recession: lessons from microeconomics data. American Economic Review 2010; 100: 51-56.

[15] Bliss B A, Cheng Y, Denis D J. Corporate payout, cash retention, and the supply of credit: Evidence from the 2008-2009 credit crisis. Journal of Financial Economics 2015; 115: 521-540.

[16] McConnell J J, Servaes H. Equity ownership and the two faces of debt. Journal of Financial Economics 1995; 39: 131-157.

[17] Almeida H, Campello M, Weisbach M S. The cash flow sensitivity of cash. Journal of Finance 2004, 59(4), 1777-1804.

[18] Faulkender M, Wang R. Corporate financial policy and the value of cash. Journal of Finance 2006; 61: 1957-1990.

[19] Duchin R, Ozbas O, Sensoy B A. Costly external finance, corporate investment, and the subprime mortgage credit crisis. Journal of Financial Economics 2010; 97: 418-435.

[20] Iona A, Leonida L, Ventouri A. Does executive ownership lead to excess target cash? The case of UK firms. Corporate Governance 2012;17(5): 876-895.

[21] Almeida H, Campell M, Weisbach M S. Corporate financial and investment policies when future financing is not frictionless. Journal of Corporate Finance 2011; 17: 675-693.

[22] Acharya V V, Almeida H, Campello M. Is cash negative debt? A hedging perspective on corporate financial policies. Journal of Financial Intermediation 2007;16: 515-554. 